\title{
The Caprellidea (Crustacea: Peracarida: Amphipoda) from the Gulf of Mexico with a description of a new species of Paracaprella
}

\author{
IGNACIO WINFIELD and MANUEL ORTIZ \\ Laboratorio de Crustáceos, Facultad de Estudios Superiores Iztacala, UNAM. Avenida de los Barrios 1, Los Reyes Iztacala, \\ Tlalnepantla, Estado de México, México, C.P. 54090. E-mail: ignacioc@unam.mx
}

\begin{abstract}
SUMMARY: A new species of caprellid amphipod of the genus Paracaprella is described and illustrated in detail. All the material reported was collected from coral rubble samples from the Arrecife Tuxpan/Lobos Protected Natural Area, off Veracruz State, Mexico, WSW Gulf of Mexico. The new species is characterized by large eyes; article 2 of peduncle of antenna 2 with a distoventral process; body dorsally setose; large subrectangular projection on the anteroventral margin of pereonite 2; basis of gnathopod 2 elongate and thin with a proximal knob on posterior margin, propodus longer than broad, with a robust grasping spine, and a large and robust tooth distally; and pereopods 5, 6 and 7 with several long plumose setae. The new species increases the numbers of Paracaprella species recorded around the world to 8 , and the caprellid species from the Gulf of Mexico to 16. All caprellid amphipod species documented from this gulf inhabit the coastal zone and six in the deep sea. In addition, the number of caprellid species decreases along the bathymetric gradient: 15 species on the littoral zone, 6 on the continental shelf, 5 on the continental slope, and 3 on the abyssal plain.
\end{abstract}

Keywords: Crustacea, Paracaprella, new species, coral reef, Mexico, taxonomy.

RESUMEN: Caprellidea (Crustacea: Peracarida: Amphipoda) del Golfo de México con la descripcion de una especie NUEVA DE PARACAPRELLA. - Se describe e ilustra con detalle una especie nueva de anfípodo caprélido del género Paracaprella. Todo el material estudiado fue encontrado en muestras de restos de coral del Área Natural Protegida Lobos/Tuxpan, Estado de Veracruz, SO del Golfo de México. La especie nueva se caracteriza por tener ojos grandes; artejo 2 del pedúnculo de la antena 2 con un proceso distoventral; cuerpo setoso dorsalmente, proyección subrectangular larga sobre margen anteroventral de pereonite 2; basis del gnatópodo 2 alargada y delgada con una protuberancia proximal sobre margen posterior, propodus más largo que ancho, con una espina robusta raspadora, y un diente robusto y largo distalmente; pereiópodos 5, 6 y 7 con algunas setas plumosas largas. La especie nueva incrementa el número de especies del género Paracaprella registradas en el mundo a ocho, y a 16 las especies de caprélidos para el golfo de México. Todas las especies documentadas para el golfo habitan en la costa y seis especies en el mar profundo. Además, el número de especies de caprélidos decrece a lo largo del gradiente batimétrico: 15 especies en la zona litoral, seis en la plataforma continental, cinco en el talud continental, y tres en la planicie abisal.

Palabras clave: Crustacea, Paracaprella, especie nueva, arrecife de coral, México, taxonomía.

\section{INTRODUCTION}

Caprellids are benthic amphipods distributed from the intertidal zone to abyssal depths (Guerra-García et al. 2008) and associated with algae, seagrasses, sponges, hydroids, bryozoans, tunicates, shell debris, coral rubbles, and soft bottoms (McCain 1968). These small marine crustaceans (millimetres to a few centimetres) are a food resource for some invertebrates and fish in coastal ecosystems (Guerra-García 2004, Woods 2009) and are considered excellent bioindicators (GuerraGarcía and García-Gómez 2001).

So far, 401 caprellid species grouped into 88 genera have been recorded worldwide (Ahyong et al. 2011). Caprellid amphipods have been subjected to various controversial phylogenetic analyses (Laubitz 1976, 
1993, Takeuchi 1993, Myers and Lowry 2003, Ito et al. 2008,2011 ), showing the acquisition of a single body plan with a reduction of the posterior body segments and the thoracic legs. It includes a cylindrical and elongated body, head and pereonite 1 fused, rudimentary coxae, two pairs of gills, oostegites on pereonites 3 and 4 , pereopods 3 and 4 absent, reduced or well developed, and a degenerative abdomen and abdominal appendages (Ito et al. 2011). The genus Paracaprella Mayer, 1890 is characterized by a reduction to 2 articles in pereopods 3 and 4, antenna 2 has a 2 -articulated flagellum, mandibular palp is reduced to one seta, or when present it has 2 or 3 minute segments, and the abdomen of the male has one pair of appendices and one pair of lobules (McCain 1968, Guerra-García 2003a).

Prior to this study, seven nominal Paracaprella species had been described worldwide. Paracaprella pusilla Mayer, 1890 and P. tenuis Mayer, 1903 are recorded from the Gulf of Mexico as epibiotic organisms associated with hard substrates, seagrasses and macroalgae (McCain 1968, Escobar-Briones and Winfield 2003, Winfield et al. 2006, LeCroy et al. 2009).

During a general research project focused on recording the biodiversity of the amphipod crustaceans associated with the coral reefs of the Veracruz State, Mexico, SW Gulf of Mexico, some specimens of Paracaprella were collected in the Arrecife Tuxpan/Lobos Protected Natural Area, off Veracruz State (WSW Gulf of Mexico), associated with coral rubble Acropora cervicornis (Lamarck 1816). This study describes a new species of Paracaprella and updates the caprellid amphipod checklist from the Gulf of Mexico occurring from the littoral zone to the abyssal plain, and provides the geographic distribution pattern of the genus Paracaprella around the world.

\section{MATERIALS AND METHODS}

The Tuxpan-Lobos reef system is located on the continental shelf of Veracruz State, Mexico, WSW Gulf of Mexico, at $21^{\circ} 00^{\prime} 55.59^{\prime \prime}$ to $21^{\circ} 33^{\prime} 08.47^{\prime \prime} \mathrm{N}$ and $97^{\circ} 10^{\prime} 30.85^{\prime \prime}$ to $97^{\circ} 18^{\prime} 00.23^{\prime \prime} \mathrm{W}$ (Fig. 1). The reef system includes six reefs grouped into two sectors: Lobos, with the Blanquilla, Medio and Lobos reefs; and Tuxpan, with the Tanhuijo, Enmedio and Tuxpan reefs, all characterized as shelf-type with a maximum depth of $25 \mathrm{~m}$ (Chávez et al. 1970).

Samples of coral rubble were collected manually using SCUBA diving at a depth of $16 \mathrm{~m}$. On board, $5.0 \mathrm{ml}$ of an alcohol/formalin (1:1) solution was added to make the crustaceans leave the coral surface, and then the specimens were sieved through a $0.4 \mathrm{~mm}$ mesh and conserved in 70\% ethanol. Specimens of Paracaprella were examined, dissected and illustrated in detail using a MOTIC SMZ-168 dissecting microscope equipped with a camera lucida. Bucal parts and small appendages were illustrated using a MOTIC BA-210 compound-microscope, also equipped with a camera lucida. Illustrations were completed using the

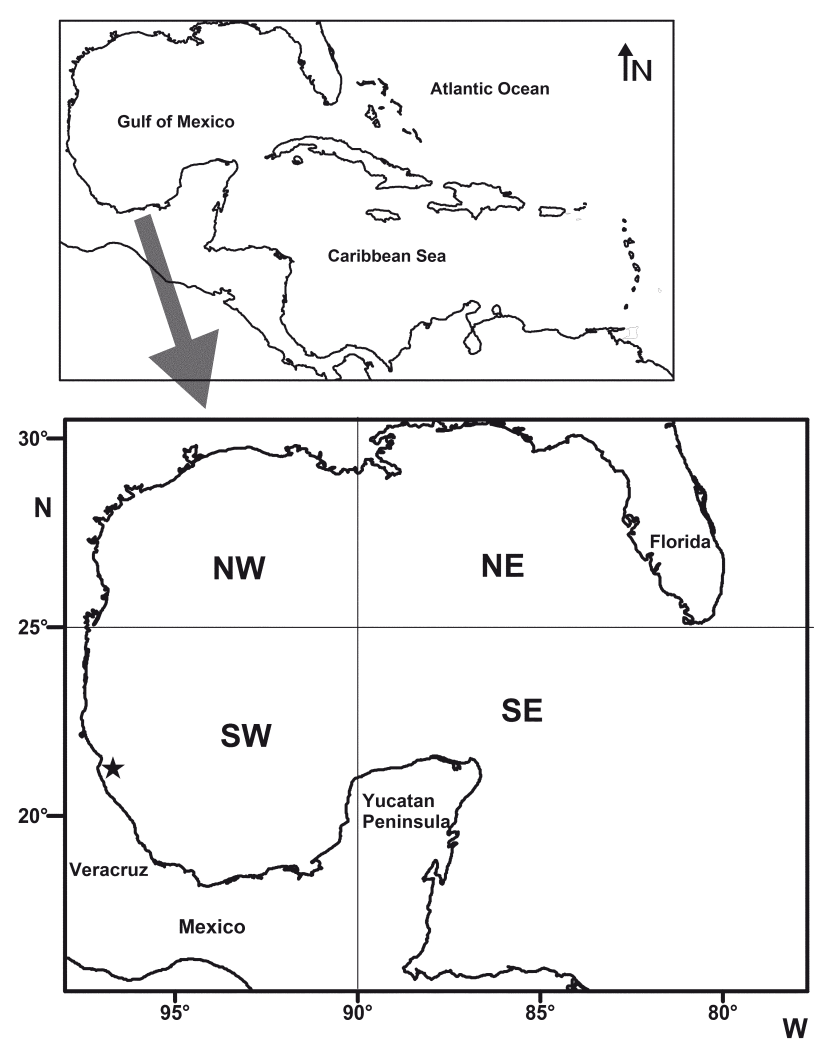

FIG. 1. - Map of the Gulf of Mexico showing the four sectors and the sampling locality.

Corel Draw V.12 program. All measurements of type material (holotype and paratype) were made with the Motic Images Plus V.2 program. The names used for the structures, setae/spines, descriptions, remarks, and morphological comparisons were based on McCain (1968), Quitete (1971), Guerra-García (2002, 2004), Diaz et al. (2005) and Guerra-García et al. (2006). The classification system of Myers and Lowry (2003), considering Superfamily Caprelloidea, Family Caprellidae, and Subfamily Caprellinae, was adopted in this study. The type material of the caprellid amphipods is deposited in the Colección Nacional de Crustáceos (CNCR), Instituto de Biología, UNAM, Mexico City.

\section{SYSTEMATICS}

Order AMPHIPODA Latreille, 1816 Suborder COROPHIIDEA Leach, 1814 Infraorder CAPRELLIDA Leach, 1814 Superfamily CAPRELLOIDEA Leach, 1814 Family CAPRELLIDAE Leach, 1814 Subfamily Caprellinae Leach, 1814 Genus Paracaprella Mayer, 1890

Paracaprella guerragarciai n. sp. (Figs 2-5)

Material examined. Holotype: adult male (used for drawings), 3.6 $\mathrm{mm}$ total length (CNCR\#26736), collected from the type locality, June 13, 2011, coll. I. Winfield. Paratype: 1 female (used for drawings), $2.8 \mathrm{~mm}$ total length (CNCR\#26737), collected from the type locality, June 13, 2011; coll., I. Winfield. 


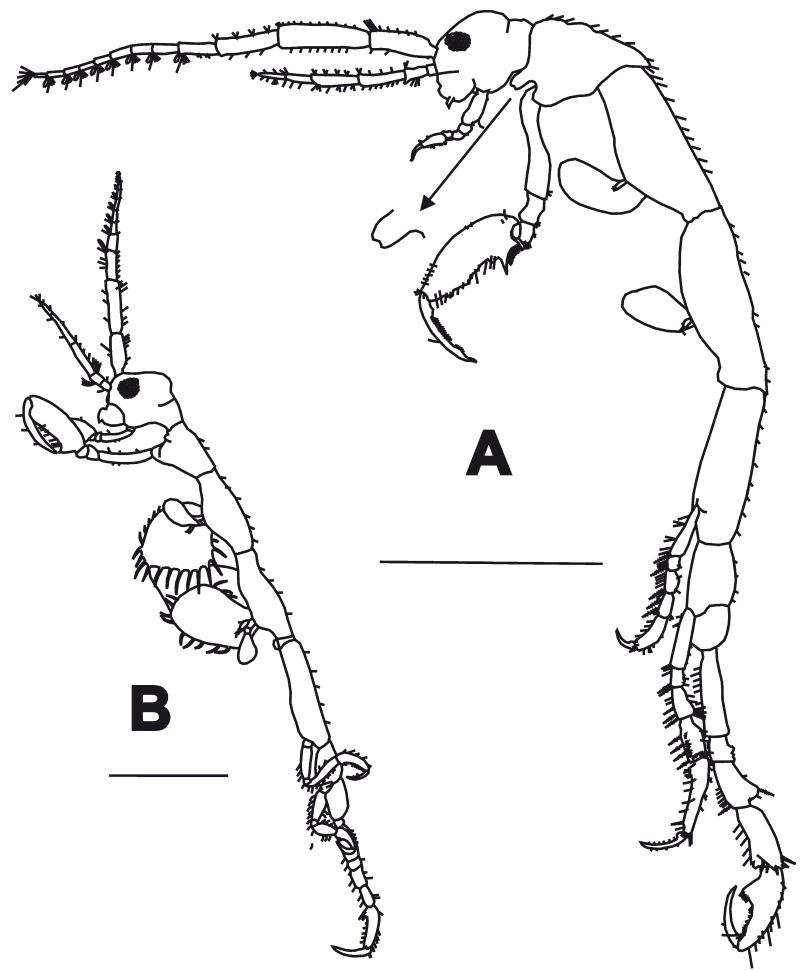

FIG. 2. - Paracaprella guerragarciai $\mathrm{n}$. sp., holotype male $(3.6 \mathrm{~mm}$ total length): A, habitus; paratype female (2.8 mm total length): $\mathrm{B}$, habitus. Scale bars: A, $1.0 \mathrm{~mm} ; \mathrm{B}, 0.7 \mathrm{~mm}$.
Additional material examined: two males (3.1 mm total length; 2.9 $\mathrm{mm}$ total length), two females $(2.1 \mathrm{~mm}$ total length; $2.0 \mathrm{~mm}$ total length) (CNCR\#26738); all material was collected from the type locality; June 13, 2011; coll., I. Winfield.

Type locality. All the material was collected from coral rubble (Acropora cervicornis) at $16 \mathrm{~m}$ depth in the Lobos Coral Reef (Lobos zone), Arrecife Tuxpan/ Lobos Protected Natural Area, off Veracruz State, Mexico $\left(21^{\circ} 28^{\prime} 20.5^{\prime}{ }^{\prime} \mathrm{N}, 97^{\circ} 13^{\prime} 52.4\right.$ 'W), WSW Gulf of Mexico, June 13, 2011.

Diagnosis. Head $4 \times$ length of pereonite 1; large eyes, almost $1 / 3 \times$ length of head, compound, 35-37 ommatida; article 2 of antenna 2 with a distoventral process; suture between head and pereonite 1 present; body dorsally setose; large subrectangular projection on anteroventral margin of pereonite 2; basis of gnatopod 2 elongate and thin with a proximal knob on posterior margin, propodus longer than broad, with a robust grasping spine, and a large and robust tooth distally; pereopods 3 and 4 short, both 2-articulated; pereopods 5, 6 and 7 with several long plumose setae.

Description. Holotype, adult male (CNCR\#26736), total length $3.6 \mathrm{~mm}$.

Lateral view (Fig. 2A). Head rounded, broader than large, $4 \times$ length of pereonite 1 ; eyes rounded, large, 35-37 ommatida; suture between head and pereonite 1

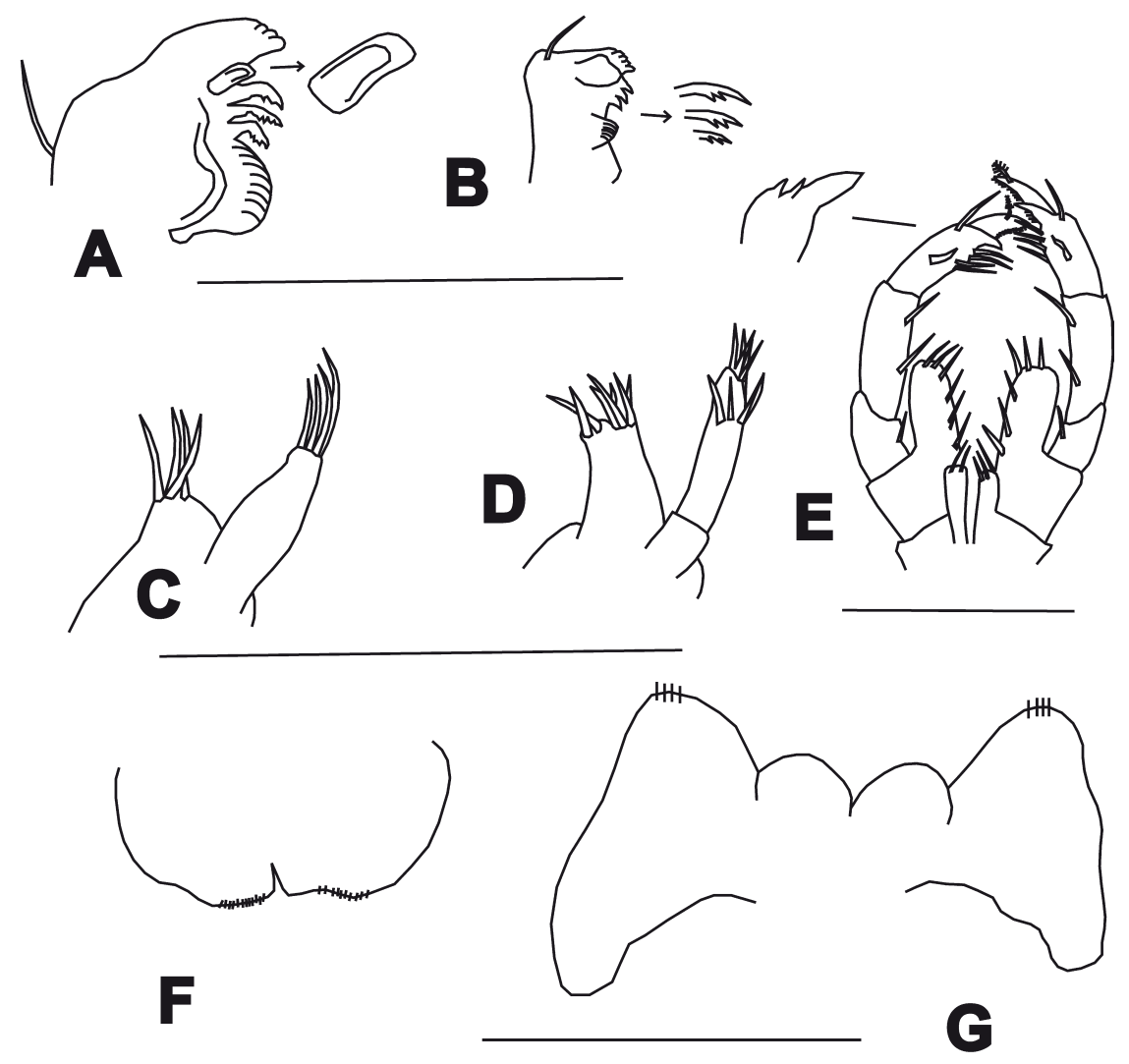

Fig. 3. - Paracaprella guerragarciai $\mathrm{n}$. sp., holotype male (3.6 mm total length): A, right mandible; B, left mandible; C, maxilla 1; D, maxilla 2; E, maxilliped (detail of article 3); F, upper lip; G, lower lip. Scale bars: A, B, $0.25 \mathrm{~mm}$; C, D, E, $0.15 \mathrm{~mm}$; F, G, 0.08 mm. 


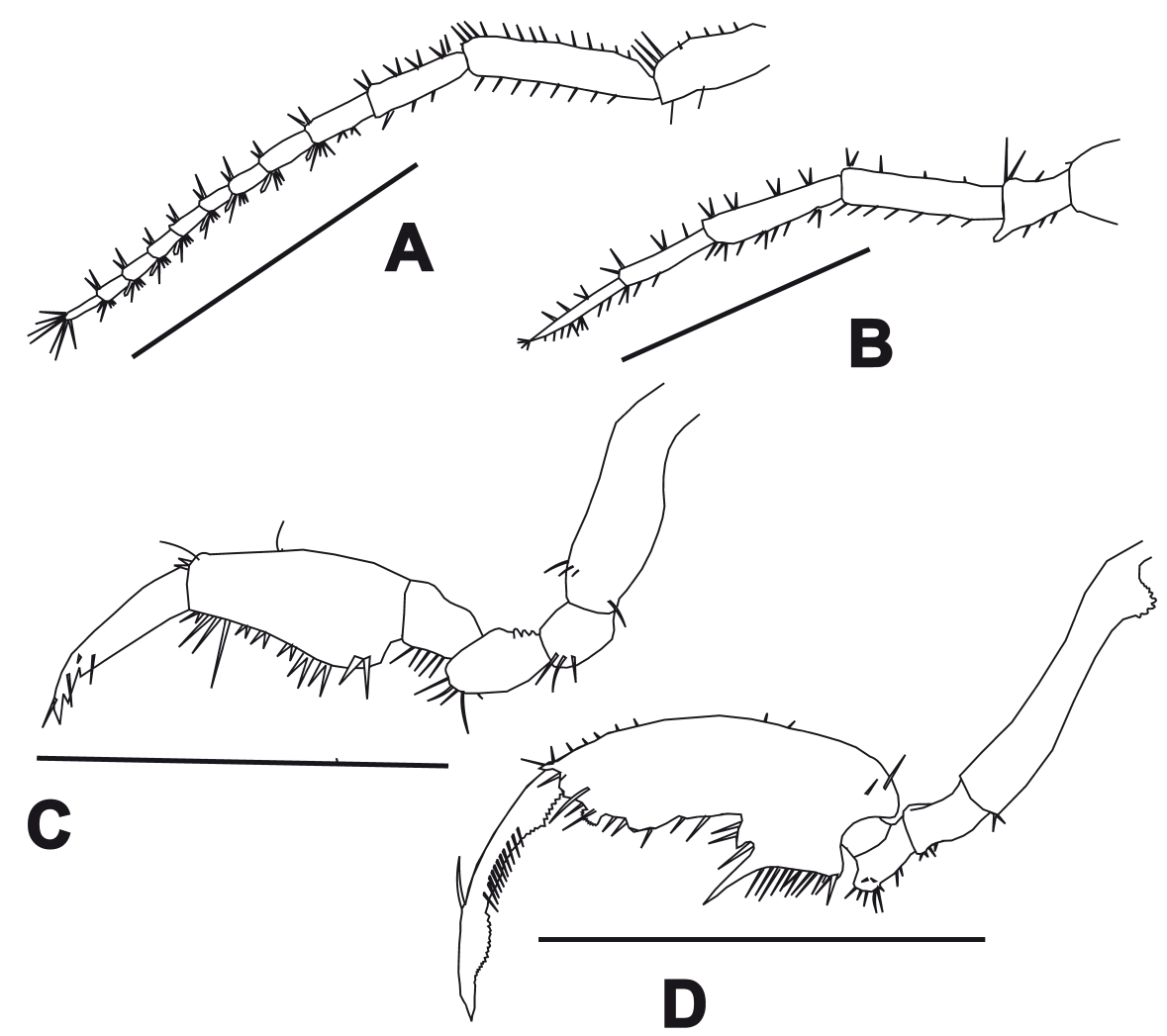

FIg. 4. - Paracaprella guerragarciai $\mathrm{n}$. sp., holotype male (3.6 mm total length): A, antenna 1; B, antenna 2; C, gnathopod 1; D, gnathopod 2. Scale bars: A, $0.9 \mathrm{~mm}$; B, $0.4 \mathrm{~mm}$; C, $0.2 \mathrm{~mm}$; D, $0.7 \mathrm{~mm}$.

present; body dorsally setose without tubercles or process; large subrectangular projection on anteroventral margin of pereonite 2; pereonites 3, 4 and 5 subequal in length and broad; pereonite 7 the shortest.

Gills (Fig. 2A). Gills on pereonites 3-4 elongate, almost $3 \times$ longer than wide.

Mouthparts (Fig. 3). Mandible palp (Fig. 3A, B) represented by a simple seta; molar process present; lacinia mobilis smooth; incisor 4-toothed (right), 5-toothed (left); 3 setal row. Maxilla 1 (Fig. 3C) outer lobe with seven robust-stout setae, proximal article of palp without setae, distal article with three distal and three medial robust-stout setae. Maxilla 2 (Fig. 3D) inner lobe oval and outer lobe elongate, both carrying four setae apically. Maxilliped (Fig. 3E) inner plate lobated with two subdistal robust setae; outer plate lobated with seven submarginal robust setae; palp 4-articulated, article 3 with a large process and two minutes ones distally, article 4 with a row of setulae on grasping margin, and a large plumose seta subdistally. Upper lip (Fig. 3F) bilobated, with a row of minute setae distally. Lower lip (Fig. 3G) smooth, inner and outer lobes wellmarked, outer lobe with four short setae distally.

Antennae (Fig. 4A, B). Antenna 1 (Fig. 4A) as long as the combined lengths of head and pereonites 1-3; peduncle 3-articulated, setose; flagellum 9-articulated. Antenna 2 (Fig. 4B) a little shorter than peduncle of antenna 1; swimming setae absent; peduncle 4-articulated, article 2 with a short process distal ventrally; flagellum 2-articulated, the two articles subequal in length.

Gnathopods (Figs 2A, 4C, D). Gnathopod 1 (Fig. 4C), basis as long as ischium, merus and carpus combined; merus with three proximal short processes on dorsal margin; propodus with two proximal-submarginal grasping robust setae; grasping margin of propodus with several robust setae; ventral margin of dactylus with three distal teeth. Gnathopod 2 inserted in the middle of pereonite 2 (Fig. 2A), basis elongated (Fig. 4D), longer than ischium, merus and carpus combined, with a proximal serrated knob on ventral margin; propodus with a quadrate projection proximally, carrying a distal long-robust tooth, a notch, and proximal grasping seta, grasping margin setose; dactylus thickened medially and setose, a short knob subdistally, grasping margin serrated.

Pereopods (Fig. 5A-E). Pereopods 3 and 4 (Fig. 5A, B) 2-articulated, basal article with a simple seta, distal article with three setae, subapically. Pereopods 5, 6 and 7 (Fig. 5C-E) increasing in length in posterior direction, ventral margins setose with several plumose setae; carpus of pereopod 7 (Fig. 5C) with two distal notches and three robust setae; propodus expanded proximally, first half of palm serrated with three grasping setae, distal half with six short grasping setae, another longer, two small distal knobs; palm of pereopod 6 (Fig. 5D) with two short proximal knobs, each bearing a pair of simple grasping setae; other three robust 


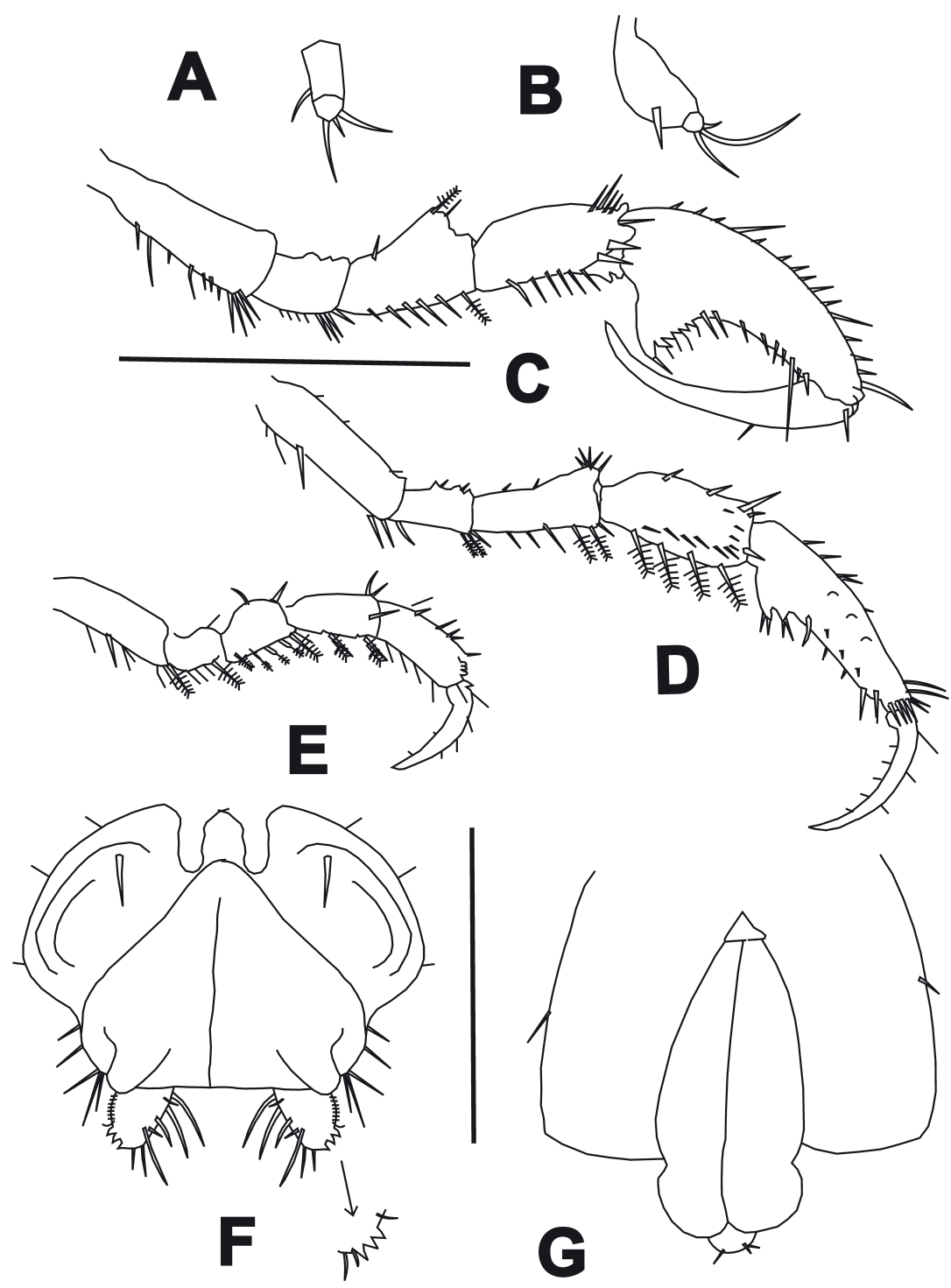

Fig. 5. - Paracaprella guerragarciai n. sp., holotype male (3.6 mm total length): A, pereopod 3; B, pereopod 4; C, pereopod 7; D, pereopod 6; E, pereopod 5; F, abdomen male (detail of distal margin); G, abdomen female. Scale bars: A, B, 0.35 mm; C, D, E, 0.5 mm; F, G, 0.03 mm.

grasping setae, and a row of five robust setae distally; propodus of pereopod 5 (Fig. 5E) with three small subdistal knobs on dorsal margin.

Abdomen (Fig. 5F). Male with a pair of short penes, a pair of uni-articulate appendages and a pair of lateral lobes, each bearing several simple setae and three short processes, marginally.

Paratype female (CNCR\#26737). Mature female (Fig. 2B), total length $2.8 \mathrm{~mm}$. Similar to male, except for the following morphological characters: flagellum of antenna 16 -articulated; oostegites present on pereonites 3 and 4, setose marginally; gnathopod 2 inserted on the anterior half of pereonite 2, basis elongate; subequal to propodus in length; subrectangular projection on anteroventral margin of pereonite 1 minute; abdomen (Fig. $5 \mathrm{G}$ ) with a pair of lateral lobes, longer than wide; and a single dorsal lobe carrying three simple setae.
Habitat. All specimens of Paracaprella guerragarciai n. sp., (3 males and 3 females) were collected from coral rubble (Acropora cervicornis) at $16 \mathrm{~m}$ depth. The sampling site is dominated by the following corals: Acropora palmata Lamarck, 1816, A. cervicornis, Diploria clivosa (Ellis and Solander, 1786), Porites astreoides Lamarck, 1816, and Montastraea cavernosa Linnaeus, 1767, and algal mats (such as Halimeda opuntia (Linnaeus) J.V. Lamouroux, 1816, Dictyota dichotoma (Hudson) J.V. Lamouroux, 1809, and Ulva reticulata Forsskål, 1775).

Etymology. This new species is named in honour of Dr. José Manuel Guerra-García, a renowned carcinologist of the University of Seville, Spain, for his valuable contribution to the study of taxonomy and phylogeny of caprellids worldwide. 
TABle 1. - Main morphological differences between males of Paracaprella guerragarciai n. sp. and the three closely related species $P$. digitimanus, $P$. pusilla and P. tenuis.

\begin{tabular}{|c|c|c|c|c|}
\hline & P. guerragarciai n. sp. & $P$. digitimanus & P. pusilla & P. tenuis \\
\hline Eye & Large, multi-ommatida & Minute & Small & Small, multi-ommatida \\
\hline $\begin{array}{l}\text { Anteroventral projection } \\
\text { on pereonite } 2\end{array}$ & Large and subquadrate & Small and subtriangular & Large and sharp-pointed & Small and triangular \\
\hline Pereonites 3, 4 and 5 & Subequal in length & $\begin{array}{l}3 \text { and } 4 \text { subequal in length, } \\
5 \text { larger and more elongate } \\
\text { than } 3 \text { and } 4\end{array}$ & Subequal in length & $\begin{array}{l}3 \text { and } 4 \text { subequal in length, } \\
5 \text { larger and more elongate } \\
\text { than } 3 \text { and } 4\end{array}$ \\
\hline Antenna 1 & Flagelum 9-articulated & Flagellum 9-articulated & Flagelum 8-articulated & Flagellum 7-articulated \\
\hline Antenna 2 & $\begin{array}{l}\text { Article } 2 \text { of peduncle with } \\
\text { a distoventral process }\end{array}$ & $\begin{array}{l}\text { Without distoventral } \\
\text { process }\end{array}$ & $\begin{array}{l}\text { Article } 1 \text { of peduncle with } \\
\text { a distoventral process }\end{array}$ & $\begin{array}{l}\text { Article } 1 \text { of peduncle with } \\
\text { a distoventral process }\end{array}$ \\
\hline Pereopods 5-7 & Several long plumose setae & No plumose setae & No plumose setae & No plumose setae \\
\hline Abdomen & $\begin{array}{l}\text { Penes elongate and short, } \\
\text { appendages short, lateral } \\
\text { lobes with three subdistal } \\
\text { processes }\end{array}$ & $\begin{array}{l}\text { Penes short, appendages large } \\
\text { and serrated apically, lateral } \\
\text { lobes setose }\end{array}$ & $\begin{array}{l}\text { Penes expanded and short, } \\
\text { appendages short, lateral } \\
\text { lobes setose }\end{array}$ & $\begin{array}{l}\text { Penes short, appendages } \\
\text { elongate, lateral lobes with } \\
\text { two setae, each one }\end{array}$ \\
\hline
\end{tabular}

Distribution. Paracaprella guerragarciai n. sp., is only known from the Lobos Coral Reef, Lobos/Tuxpan Marine Protected Area, off Veracruz State, Mexico.

Remarks. Paracaprella guerragarciai n. sp. is morphologically most similar to Paracaprella digitimanus Quitete, 1971, P. pusilla and P. tenuis; however, males of Paracaprella guerragarciai $\mathrm{n}$. sp. can be easily distinguished from those three Paracaprella species by the following characters: (1) P. guerragarciai n. sp. has eyes large and multi-ommatida, while eyes are minute to small in the other three species; (2) the dorsal margin is setose in $P$. guerragarciai $n$. sp., but smooth in the other three species; (3) anteroventral projection on pereonite 2 is large and subquadrate in $P$. guerragarciai $\mathrm{n}$. sp., but small to large and subtriangular to sharp-pointed in the other three species; (4) gnathopod 2 with a very large robust tooth on proximal quadrate projection and dactylus with inner margin serrate in P. guerragarciai n. sp., but with a short robust tooth and smooth inner margin in the other three species; and (5) several long plumose setae are present on pereopods 5-7 in $P$. guerragarciai $\mathrm{n}$. sp., but setae are longer and simpler in the other three species. The main differences are summarized in Table 1.

\section{DISCUSSION}

The genus Paracaprella, established by Mayer (1890), presently includes eight species: Paracaprella alata Mayer, 1903; Paracaprella barnardi McCain, 1967; Paracaprella crassa Mayer, 1903; Paracaprella digitimanus; Paracaprella insolita Arimoto, 1980; Paracaprella pusilla; Paracaprella tenuis; and Paracaprella guerragarciai $\mathrm{n}$. sp.

The global geographic distribution of the genus Paracaprella is mostly from $40^{\circ} \mathrm{N}$ to $20^{\circ} \mathrm{S}$, corresponding to temperate, subtropical and tropical seas (Fig. 6). Based on this geographic pattern, five species $(P$. alata, $P$. digitimanus, $P$. pusilla, $P$. tenuis and $P$. guerragarciai n. sp.) are recorded from the western Atlantic coasts, in contrast with the shallow waters of the Indian Ocean and the western Pacific (the latter including the Sea of China, the Sea of Japan and the eastern coast of Australia), with four species each (Fig. 6); only Paracaprella alata and P. pusilla are distributed worldwide, even at higher latitudes, with the exception of polar zones. Ros and Guerra-García (2012) reported $P$. pusilla as tropical caprellid amphipod with most of the records from the Gulf of Mexico and the Caribbean Sea. 


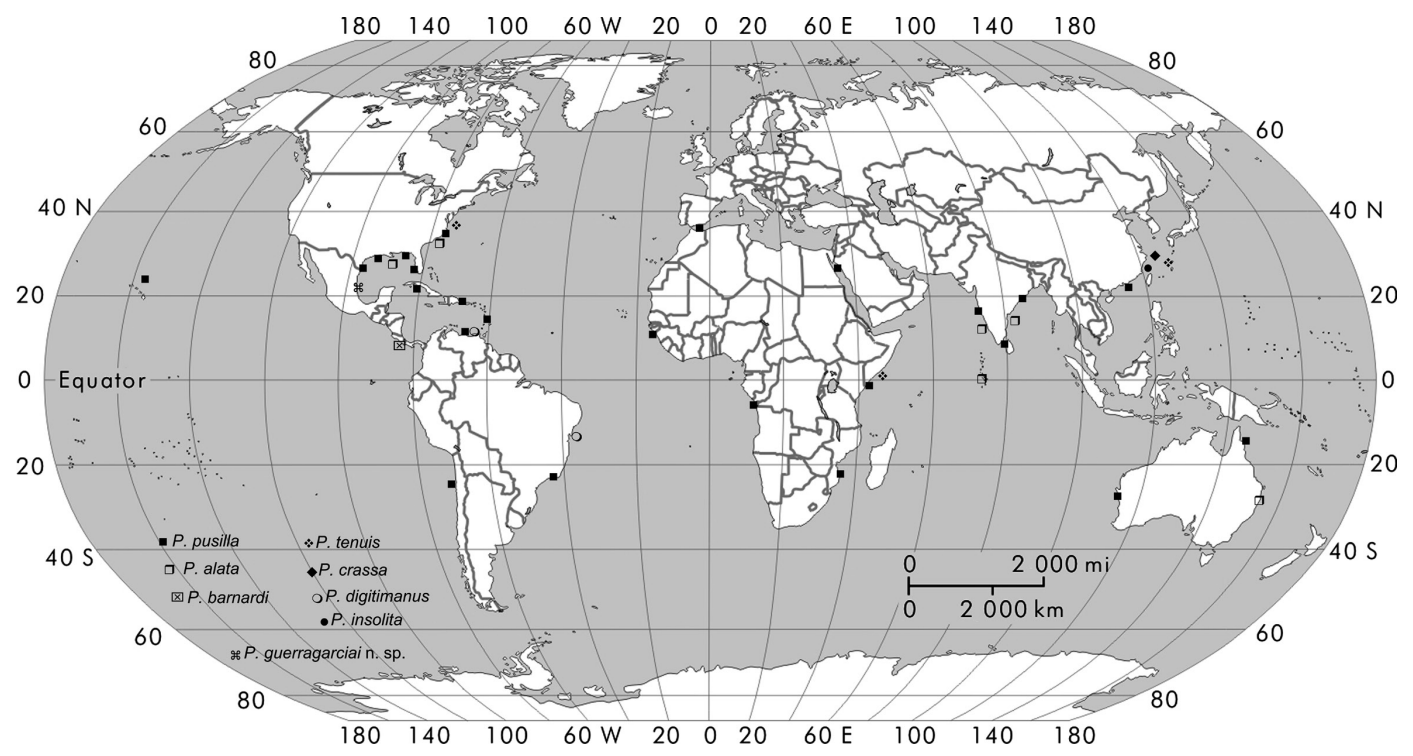

FIG. 6. - Current global distribution of all species of genus Paracaprella. Marks indicate the records where Paracaprella species have been found. Information based on Mayer 1890, 1903; McCain 1967, 1968, Arimoto 1980, Guerra-García 2002, 2003b, Díaz et al. 2005, GuerraGarcía et al. 2006, 2010, Winfield et al. 2006, 2007, Winfield and Escobar-Briones 2008, Ortiz et al. 2009, Ros and Guerra-García 2012.

So far, 16 species of caprellids (including Paracaprella guerragarciai $\mathrm{n}$. sp.) belonging to eight genera have been documented from the Gulf of Mexico: Caprella Lamarck, 1801 (5 species), Paracaprella (3 species), Deutella Mayer, 1890 (3 species), Hemiaegina Mayer, 1890, Hemiproto McCain, 1968, Metaprotella Mayer, 1890, Phtisica Slabber, 1769 and Pseudaeginella Mayer, 1890 (1 species each) (McCain 1968, Escobar-Briones and Winfield 2003, GuerraGarcía 2003b, Winfield et al. 2006, 2007, Winfield and Escobar-Briones 2008, LeCroy et al. 2009) (Table 2). All caprellid amphipod species from the Gulf of Mexico inhabit the coastal zone (0-200 m depth), and six species in the deep sea (201-3800 m depth) (Table 2). The number of species decreases along the bathymetric gradient, with the greatest number (15 species) on the littoral fringe (0-20 m depth), six species on the continental shelf (21-200 m depth), five on the continental slope (201-2000 m depth), and three on the abyssal plain (2001-3800 m depth); only Caprella equilibra Say, 1818 inhabits depths from 1 to $3800 \mathrm{~m}$ (Table 2). The species Caprella penantis Leach 1814, Deutella incerta (Mayer, 1903), Hemiaegina minuta Mayer, 1890 and Paracaprella pusilla are distributed

TABle 2. - Number of caprellid species from the Gulf of Mexico. Depth, habitat and geographic sectors in the Gulf of Mexico (see Fig. 1) are included. Information based on McCain 1968, Escobar-Briones and Winfield 2003, Guerra-García 2003a, Winfield et al. 2006, 2007, Winfield and Escobar-Briones 2008, LeCroy et al. 2009. GM, Gulf of Mexico; LF, littoral fringe; CSH, continental shelf; CSL, continental slope; AP, abyssal plain.

\begin{tabular}{|c|c|c|c|}
\hline Name of species & Depth & Habitat & Sector of GM \\
\hline Caprella andreae Mayer, 1890 & LF & Epibiotic on floating objects, hard substrate, algal mats & \\
\hline C. danilevskii Czerniavski, 1868 & LF, CSL, AP & $\begin{array}{l}\text { Epibiotic, soft bottom, seagrass, Sargassum, algal mats, } \\
\text { bryozoans }\end{array}$ & NE, SE, SW \\
\hline C. equilibra Say, 1818 & LF, CSH, CSL, AP & $\begin{array}{l}\text { Soft bottoms, seagrass, algal mats, sponges, hydroids, } \\
\text { bryozoans, tunicates }\end{array}$ & NE, NW, SW \\
\hline C. penantis Leach, 1814 & LF, AP & $\begin{array}{l}\text { Hard substrate, soft bottoms, seagrass, algal mats, } \\
\text { sponges, hydroids, bryozoans }\end{array}$ & ENTIRE \\
\hline C. scaura Templeton, 1836 & LF & Epibiotic, hard substrate, seagrass, algal mats & $\mathrm{NE}$ \\
\hline Deutella californica Mayer & LF & Epibiotic, hard substrate, algal mats, soft bottoms & NW, SW \\
\hline D. incerta (Mayer, 1903) & $\mathrm{LF}, \mathrm{CSH}, \mathrm{CSL}$ & Epibiotic, hard substrate, seagrass, soft bottoms & ENTIRE \\
\hline D. mayeri Stebbing, 1895 & LF & Unknown & $\mathrm{NE}$ \\
\hline Hemiaegina minuta Mayer, 1890 & $\mathrm{LF}, \mathrm{CSH}, \mathrm{CSL}$ & Epibiotic, hard substrates, soft bottoms, Sargassum, & ENTIRE \\
\hline Hemiproto wigleyi McCain, 1968 & $\mathrm{CSH}$ & Soft bottoms & NE, SW \\
\hline Metaprotella hummelincki McCain, 1968 & $\mathrm{LF}$ & Macrofoulers, hard substrates & SW \\
\hline Paracaprella pusilla Mayer, 1890 & $\mathrm{LF}, \mathrm{CSH}$ & $\begin{array}{l}\text { Soft bottoms; mangrove roots, seagrass, hydroids, } \\
\text { tunicates }\end{array}$ & ENTIRE \\
\hline Paracaprella guerragarciai $\mathrm{n}$. sp. & LF & Coral rubble & SW \\
\hline Paracaprella tenuis Mayer, 1903 & LF & $\begin{array}{l}\text { Epibiotic, hard substrate, seagrass, algal mats, sponges, } \\
\text { bryozoans, hydroids }\end{array}$ & NE, NW \\
\hline Phtisica marina Slabber, 1769 & $\mathrm{LF}, \mathrm{CSH}, \mathrm{CSL}$ & $\begin{array}{l}\text { Epibiotic, seagrasss, algal mats, soft bottoms, sponges, } \\
\text { hydroids, bryozoans }\end{array}$ & NE, SW, SE \\
\hline Pseudaeginella biscaynensis (McCain, 1968) & $\mathrm{LF}$ & Epibiotic, seagrass, algal mats & SE \\
\hline
\end{tabular}


throughout the four sectors of the Gulf of Mexico (Table 2). The northeastern and southwestern sectors have been studied intensively with the greatest number of benthic caprellid species (seven each), in comparison with the less studied southeastern (four species) and northwestern (three species) sectors (Table 2).

Summarizing, the numbers of caprellid amphipods known to inhabit the shallow waters and deep sea in the Gulf of Mexico will increase with further sampling, especially from soft bottoms, hard substrates, algal mats, seagrasses, sponges, hydroids, bryozoans, and shell debris, on oceanographic cruises to be carried out in the coming years in this Large Marine Ecosystem.

\section{ACKNOWLEDGEMENTS}

We gratefully acknowledge the funds obtained through grants from the PAPIME-PE207311 and PAPIIT-IN229011 projects, both of Universidad Nacional Autonoma de Mexico. The authorities of CONAPESCA-DGOPA (02921.290411.1172) of the Agriculture and Fisheries Secretariat (SAGARPA), and the administrators of the Arrecife Tuxpan/Lobos Area Natural Protegida, Veracruz, are also thanked for granting the necessary permits to sample within the coral reef. We thank in particular M.A. LozanoAburto, who helped with the sub-aquatic activities.

\section{REFERENCES}

Ahyong S.T., Lowry J., Alonso M., Bamber R.N., Boxshall G.A., Castro P., Gerken S., Karaman G.S., Goy J.W., Jones D.S., Meland K., Rogers D.Ch., Svavarsson J. 2011. Subphylum Crustacea Brünnich, 1772. In: Zhang Z.Q. (eds), Animal biodiversity, an outline of higher-level classification and survey of taxonomic richness. Zootaxa 3148:165-191.

Chávez E., Hidalgo E., Sevilla M. 1970. Datos acerca de las comunidades bentónicas del arrecife Lobos, Ver. Rev. Soc. Mex. Hist. Nat. 31: 211-218.

Díaz Y.J., Guerra-García J.M., Martín A. 2005. The Caprellidea (Crustacea: Amphipoda) from Venezuela. Org. Div. Evol. 5: 249-251.

Escobar-Briones E., Winfield I. 2003. Checklist of Benthic Gammaridea and Caprellidea (Crustacea: Peracarida: Amphipoda) from the Gulf of Mexico Continental Shelf and Slope. Belg. J. Zool. 113(1): 37-44.

Guerra-García J.M. 2002. Redescription of five rare caprellids (Crustacea: Amphipoda) collected from Tanzanian coasts. Helgol. Mar. Res. 55: 221-231.

Guerra-García J.M. 2003a. Revision of the genus Deutella (Crustacea: Amphipoda: Caprellidea) with description of a new species, redescription of Deutella venenosa Mayer, 1890 and a key to the species of Deutella. J. Nat. Hist. 37: 1059-1084.

Guerra-García J.M. 2003b. The Caprellidea (Crustacea, Amphipoda) from Mauritius Island, Western Indian Ocean. Zootaxa, 232: $1-24$

Guerra-García J.M. 2004. The Caprellidea (Crustacea: Amphipoda) from Western Australia and Northern Territory, Australia. $\mathrm{Hy}$ drobiologia 522: 1-74.

Guerra-García J.M., García-Gómez J.C. 2001. The spatial distribution of Caprellidea (Crustacea: Amphipoda): a stress bioindicator in Ceuta (North Africa, Gibraltar area). PSZNI Mar. Ecol. 22(4): 357-367.

Guerra-García J.M., Krapp-Schickel T., Müller H.G. 2006. Caprel- lids from the Caribbean coast of Colombia, South America, with description of three new species and a key for species identification. Bol. Inv. Mar. 35: 149-194.

Guerra-García J.M., Sorbe J.C., Frutos I. 2008. A new species of Liropus (Crustacea, Amphipoda, Caprellidae) from Le Danois bank (southern Bay of Biscay). Org. Div. Evol. 7(4): $253 \mathrm{e} 1-253 \mathrm{e} 12$.

Guerra-García J.M., Ganesh T., Jaikumar M., Raman A.V. 2010. Caprellids (Crustacea: Amphipoda) from India. Helgol. Mar. Res. 64: 297-310.

Ito A., Wada H., Aoki M.N. 2008. Phylogenetic analysis of caprellid and corophioid amphipods (Crustacea) based on the 18S rRNA gene, with special emphasis on the phylogenetic position of Phtisicidae. Biol. Bull. 214: 176-183.

Ito A., Masakazu N., Yahata A., Hiroshi W. 2011. Complicated evolution of the caprellid (Crustacea: Malacostraca: Peracarida: Amphipoda) body plan, reacquisition or multiple losses of the thoracic limbs and pleons. Dev. Genes Evol. 221: 133-140.

Laubitz D.R. 1976. On the taxonomic status of the family Caprogammaridae Kudrjaschov and Vassilenko (Amphipoda). Crustaceana 31: 145-150.

Laubitz D.R. 1993. Caprellidea (Crustacea, Amphipoda)-towards a new synthesis. J. Nat. Hist. 27: 965-976.

LeCroy S., Gasca R., Winfield I., Ortiz M., Escobar-Briones E. 2009. Amphipoda of the Gulf of Mexico. In: Felder D.L., Camp D.K. (eds), Gulf of Mexico; its Origin, Waters and Biota. Texas A\&M Univ. Press, Vol I, pp. 941-972.

Mayer P. 1890. Die Caprelliden des Golfes von Neapel und der angrenzenden Meeres-Abschnitte. Fauna und Flora des Golfes von Neapel 17: 1-55.

Mayer P. 1903. Die Caprellidae der Sigoba Expedition. Sigoba Exped. 34: 1-160.

McCain J.C. 1967. Paracaprella barnardi, a new species of caprellid (Crustacea: Amphipoda) from the West Coast of Panama. Proc. Biol. Soc. Wash. 80: 219-222.

McCain J.C. 1968. The Caprellidae (Crustacea: Amphipoda) of the western North Atlantic. U.S. Natl. Mus. Bull. 278: 1-147.

McCain J.C., Steinberg J.E. 1970. Amphipoda-I, Caprellidea-I, Crustaceorum Catalogus 2: 1-78.

Myers A.A., Lowry J.K. 2003. A phylogeny and a new classification of the Corophiidea Leach, 1814 (Amphipoda). J. Crust. Biol. 23: 443-485.

Ortiz M., Guerra-García J.M., Lalana R. 2009. Cubadeutella cavernicola, a new genus and species of Caprellidae (Crustacea: Amphipoda) from Cuba. Zootaxa 2130: 60-68.

Quitete J. 1971. Paracaprella digitimanus, nova espécie de Caprellidae da costa brasileira (Crustacea: Amphipoda). Atas Soc. Biol. Rio do Janeiro 14: 161-164.

Ros M., Guerra-García J.M. 2012. On the occurrence of the tropical caprellid Paracaprella pusilla Mayer, 1890 (Crustacea: Amphipoda) in Europe. Medit. Mar. Sci. 13(1): 134-139.

Takeuchi I. 1993. Is the Caprellidea a monophyletic group? J. Nat. Hist. 27: 947-964.

Winfield I., Escobar-Briones E. 2008. Composición, dominancia y distribución batimétrica de los anfípodos bentónicos (Caprellidea y Gammaridea) en la porción mexicana del Golfo de México. In: Álvarez F., Gutiérrez G. (eds), Actualización del conocimiento de los crustáceos en México. México. UANLConabio, pp. 17-32.

Winfield I., Escobar-Briones E., Morrone J.J. 2006. Updated checklist and identification of areas of endemism of benthic amphipods (Caprellidea and Gammaridea) from offshore habitats in the SW Gulf of Mexico. Sci. Mar. 70(1): 99-108.

Winfield I., Abarca-Arenas, L.G., Cházaro-Olvera, S. 2007. Crustacean macrofoulers in the Veracruz coral reef system, SW Gulf of Mexico: checklist, spatial distribution and diversity. Cah. Biol. Mar. 48: 287-295.

Woods C. 2009. Caprellid amphipods: an overlooked marine finfish aquaculture resource?. Aquaculture 289: 199-211.

Scient. ed.: J.A. Cuesta.

Received September 26, 2012. Accepted February 5, 2013.

Published online February 26, 2013. 